\title{
PENGEMBANGAN E-BOOK BERBASIS ANDROID PADA MATA PELAJARAN SISTEM KOMPUTER DI SMK YAPALIS KRIAN
}

\author{
Mokhamad Wahyu Supratama ${ }^{1}$, Cindy Cahyaning Astuti ${ }^{2 *}$ \\ Program Studi pendidikan Teknologi Informasi, Fakultas Psikologi dan Ilmu Pendidikan, Universitas \\ Muhammadiyah Sidoarjo \\ Jl. Majapahit 666B Sidoarjo \\ Telp. (031) 8945444 \\ E-mail: cindy.cahyaning@umsida.ac.id*
}

\begin{abstract}
ABSTRAKS
Penelitian tentang pengembangan E-book berbasis android pada materi Sistem Komputer ini dilatar belakangi oleh keterbatasan media yang digunakan oleh guru pada pembelajaran daring. Tujuan dari penelitian ini untuk mengetahui bagaimana pengembangan E-book pada mata pelajaran Sistem Komputer serta mengetahui kelayakan E-book pada mata pelajaran Sistem Komputer. Jenis penelitian ini adalah penelitian pengembangan dengan model yang digunakan adalah ADDIE. Teknik pengumpulan data pada penelitian ini menggunakan lembar validasi ahli dan angket respon peserta didik. Pengembangan E-book berbasis android ini menggunakan aplikasi Flip Pdf Corporate Edition. Hasil penelitian diperoleh dari ahli materi, ahli media dan angket respon peserta didik dengan persentase kelayakan media yang dinilai oleh ahli media mendapatkan presentase sebesar 96\% dengan kategori "Sangat Layak", untuk digunakan dan penilaian dari ahli materi mendapatkan presentase sebesar 84\% dengan kategori "Sangat Layak" serta respon peserta didik dalam angket siswa mendapat nilai rata-rata sebesar 91,4 dengan kategori "Sangat Layak" untuk digunakan dalam proses pembelajaran yang sesungguhnya di dalam kelas.
\end{abstract}

Kata Kunci:media pembelajaran, e-book berbasis android, sistem komputer

\begin{abstract}
This research on the development of an Android-based E-book on the Computer System material is motivated by the limitations of the media used by teachers in online learning. The purpose of this study is to find out how the development of E-books on Computer Systems subjects and determine the feasibility of E-books on Computer Systems subjects. This type of research is development research with the model used is ADDIE. Data collection techniques in this study used expert validation sheets and student response questionnaires. The development of this Android-based E-book uses the Flip Pdf Corporate Edition application. The results of the study were obtained from material experts, media experts and student response questionnaires with the percentage of media feasibility assessed by media experts getting a percentage of $96 \%$ with the "Very Eligible" category, for use and assessment from material experts getting a percentage of $84 \%$ with the category "Very Eligible" and student responses in the student questionnaire got an average score of 91.4 with the category "Very Eligible" to be used in the actual learning process in the classroom.
\end{abstract}

Keywords: learning media, android-based e-book, computer system

\section{PENDAHULUAN}

\subsection{Latar Belakang}

Perkembangan teknologi merupakan salah satu faktor yang mempengaruhi perilaku belajar siswa. Tanpa disadari peserta didik menjadi bagian dari digital native yaitu generasi yang hidup di era digital, yang dapat dengan mudah mengakses informasi dan kemudahan lainnya melalui media digital. Hal ini didukung dengan terus berkembangnya perangkat komputer dan gadget yang mendukung generasi digital native sehingga perangkat tersebut dapat dengan mudah dan cepat mengakses informasi melalui perangkat digital. Berarti sedikit banyak akan mempengaruhi gaya hidup mereka, terutama dalam hal belajar (Gatot Pramono, 2008).
Belajar bukanlah sebuah tujuan, melainkan sebuah proses untuk mencapai sebuah tujuan. Partisipasi media pembelajaran dalam proses pembelajaran diharapkan dapat mempengaruhi pengalaman belajar siswa dan tujuan yang ingin dicapai oleh pembelajaran itu sendiri. Media dapat mengungkapkan isi yang tidak dapat diungkapkan oleh guru melalui kata atau kalimat tertentu.

Penggunaan media pembelajaran berdasarkan materi yang diberikan diharapkan dapat meningkatkan minat dan motivasi siswa. Dengan cara ini, kemampuan dan tujuan belajar dapat dicapai dengan benar. Sebagaimana (Suryani \& Khoiriyah, 2018) mengatakan, media pembelajaran adalah segala sesuatu yang digunakan untuk menyampaikan informasi, yang dapat merangsang 
pikiran, perasaan, perhatian dan kemauan siswa, sehingga mendorong terjadinya proses belajar yang sadar, terarah dan terkendali.

Berdasarkan observasi yang dilakukan di SMK Yapalis Krian terhadap beberapa guru di sekolah tersebut, hasil yang diperoleh penulis adalah pembelajaran dilakukan secara daring di sekolah. Pembelajaran daring yang di lakukan ialah guru membagikan link berupa materi yang akan diajarkan melalui platform google meet sehingga siswa dapat mempelajari materi tersebut secara mandiri di rumah, guru memang kesulitan untuk menjelaskan materi tersebut karena memang waktu yang sudah di tetapkan oleh sekolah sangat terbatas apalagi materi yang di bahas ini seluruhnya teori tanpa adanya praktik sehingga memang membutuhkan penjelasan yang lengkap disertai video latihan. Di pandemi covid-19 saat ini memang beberapa guru kesulitan mengkomunikasikan seluruh isi pembelajaran kepada siswa karena media yang digunakan masih terbatas yaitu masih menggunakan media dalam bentuk Power Point. Dapat dikatakan bahwa media pembelajaran dengan menggunakan ppt masih kurang untuk memenuhi kebutuhan siswa, karena isinya terbatas seperti masih menggunakan text seperti biasa tanpa adanya video latihan.

Maka dari itu salah satu yang dibutuhkan peserta didik di era sekarang agar memudahkan siswa untuk belajar adalah media yang dapat diakses dan dipelajari kapanpun dan dimanapun, Saat ini guru juga dituntut lebih kreatif dan inovatif dalam membuat media pembelajaran agar siswa dapat belajar secara mandiri. Penggunaan teknologi Android untuk pembelajaran dapat meningkatkan minat belajar siswa, karena penggunaan media pembelajaran Android lebih kreatif tampilannya, lebih kompleks isinya, dan lebih sederhana serta mudah penggunaannya bagi siswa untuk belajar, seperti menggunakan aplikasi E-book.

E-book yang dihasilkan dapat disimpan di perangkat elektronik seperti handphone, laptop, ipad, dan sebagainya. Siswa dapat membawa materi pelajaran dan membacanya kapan saja dan dimana saja. Dengan kata lain, E-book lebih fleksibel daripada E-book. buku cetak. E-book juga memberi siswa lebih banyak waktu belajar, yang berarti siswa tidak hanya dapat mempelajari materi yang mereka pelajari selama waktu kelas.

Penelitian ini diharapkan dapat menghasilkan sebuah produk berupa media E-book berbasis android yang bisa di jalankan di masing-masing smartphone milik siswa. Media E-book ini nantinya berisi bukan hanya materi tapi juga audio dan video latihan tutotial yang bisa dijalankan tanpa internet supaya memudahkan belajar siswa.

Berdasarkan uraian latar belakang tersebut peneliti mencoba mengembangkan E-book berbasis Android pada mata pelajaran sistem komputer, maka diperoleh rumusan masalah sebagai berikut : 1 . Bagaimana pengembangan E-book berbasis Android pada mata pelajaran sistem komputer di SMK Yapalis Krian? 2. Bagaimana kelayakan E-book berbasis Android pada mata pelajaran sistem komputer di SMK Yapalis Krian?

Pada penelitian ini tujuan yang ingin dicapai peneliti adalah untuk mengetahui : 1. Pengembangkan E-book berbasis Android pada mata pelajaran sistem komputer di SMK Yapalis Krian. 2. Mengetahui kelayakan E-book berbasis Android pada mata pelajaran sistem komputer di SMK Yapalis Krian.

\subsection{Metode Penelitian}

Jenis penelitian yang digunakan adalah berupa penelitian dan pengembangan atau dikenal dengan Research and Development (R\&D). Research and Development (R\&D adalah suatu proses kegiatan atau langkah-langkah untuk mengembangkan suatu produk tertentu atau produk yang masih baru serta menyempurnakan sebuat produk yang telah ada, yang bisa dipertanggung jawabkan (Sukmadinata, 2013).

Menurut (Sugiyono, 2009) metode penelitian dan pengembangan ini adalah metode penelitian yang akan digunakan untuk menemukan, memperbaiki, mengembangkan serta menghasilkan sebuah produk tertentu dan menguji keefektifan dan kelayakan baik dari segi model dan metode produk tersebut.

Model pengembangan yang digunakan adalah model pengembangan ADDIE, yaitu merupakan komponen utama dari pendekatan sistem untuk pengembangan pembelajaran. Model pengembangan ini disebut juga perancangan instruksional yang dapat berupa proses umum yang secara tradisional digunakan pengembangan dalam pelatihan(Endang, 2011). Model ADDIE dibagi kedalam 5 tahapan, yaitu :

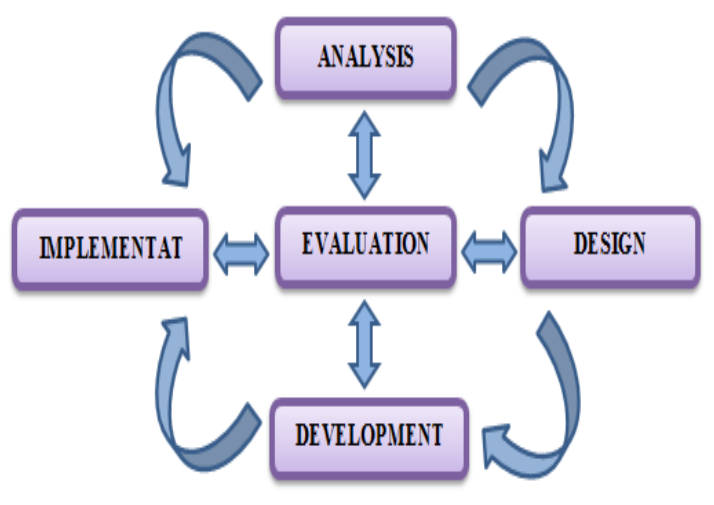

Gambar 1. Model pengembangan ADDIE (Sumber : Alwan, 2018) 
1. Tahap Analysis, diartikan sebagai analisis kebutuhan program media pembelajaran, terkait permasalahan pembelajaran, tujuan dan sasaran pembelajaran.

2. Tahap Design, diartikan sebagai perancangan dan pembuatan desain media pembelajaran.

3. Tahap Development, diartikan sebagai tahap pembuatan produk atau media pembelajaran. Tahap Implementation, diartikan sebagai pengimplementasian media pembelajaran ke siswa.

4. Tahap Evaluation, diartikan sebagai tahap evaluasi terhadap penerapan media yang dikembangkan.

\subsection{Prosedur Pengembangan}

Melalui model penelitian dan pengembangan ini, produk yang akan dihasilkan berupa media pembelajaran E-book berbasis android, yang bertujuan untuk memudahan kegiatan belajar mengajar antara pendidik dan siswa, sehingga dapat mencapai tujuan pendidikan sekolah.

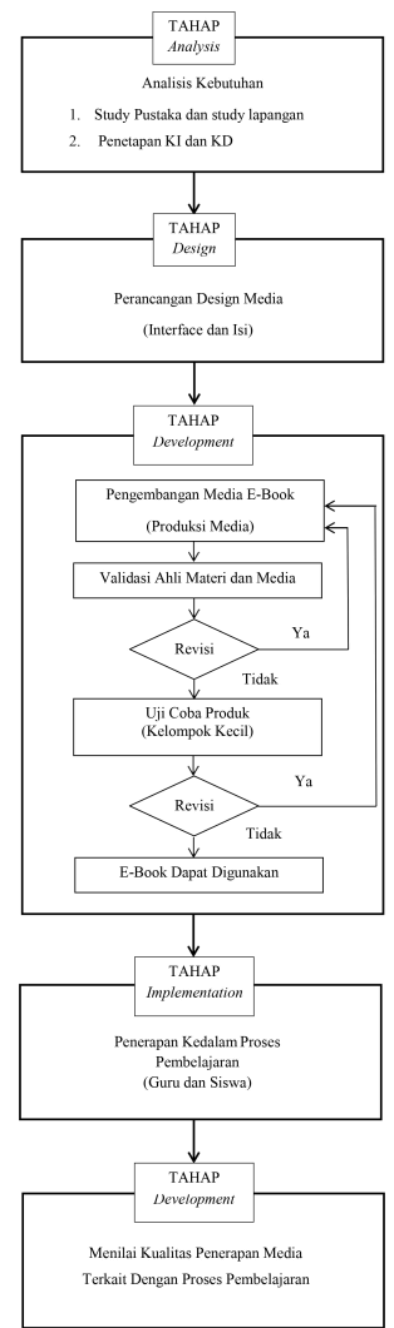

Gambar 2. Alur Proses Penelitian Pengembangan E-book
Untuk melakukan pengembangan ini dibutuhkan persiapan seperti menganalisis kebutuhan baik study pustaka maupun study lapangan, penetapan kd dan tujuan pembelajaran dan pemilihan bahan ajar yang cocok digunakan. Dengan adanya persiapan tersebut akan dapat mendukung proses penelitian dan pengembangan yang akan dilakukan. Proses alur pengembangan dapat dilihat pada Gambar 2.

\subsection{Metode Pengumpulan Data}

Metode pengumpulan data dalam penelitian Ebook berbasis Android pada mata pelajaran sistem komputer ini dengan menggunakan metode angket dan observasi. Metode angket digunakan untuk mengumpulkan informasi tentang pendapat para ahli dan guru terhadap E-book berbasis Android pada mata pelajaran sistem komputer di SMK Yapalis Krian dengan menggunakan lembar angket penilaian.

Teknik analisis data untuk mengetahui hasil penilaian media oleh ahli materi dan ahli media yang bertujuan untuk memvalidasi dari kelayakan media tersebut dalam penggunaannya pada penelitian pengembangan ini.

Tabel 1. Ketentuan Kriteria Penilaian Lembar Validasi Media

\begin{tabular}{l|c}
\hline \multicolumn{1}{c|}{ Kriteria } & Skor \\
\hline Sangat Baik & 5 \\
Baik & 4 \\
Cukup & 3 \\
Tidak Baik & 2 \\
Sangat Tidak Baik & 1 \\
\hline
\end{tabular}

1. Data yang sudah terkumpul sebelumya kemudian dihitung skor rata-rata dari setiap aspek yang dinilai, dengan rumus :

$$
\widetilde{X}=\frac{\sum X}{n}
$$

Keterangan :

$\tilde{\boldsymbol{X}}=$ skor rata-rata

$\sum \mathbf{X}=$ skor total dari penilai

$\mathbf{n}=$ jumlah data

2. Untuk melihat bagaimana kelayakan media, digunakan skala pengukuran sebagai berikut. Penghitungan rating scale ditentukan dengan rumus :

$P=\frac{\text { Jumlah } \text { skor hasil pengumpulan data }}{\text { Jumlah } \text { skor maksimum }} \times 100 \%$

Keterangan : P = Persentase kelayakan media

3. Selanjutnya hasil dari penghitungan di atas nilai pada skala ditransformasikan seperti pada Tabel 2. 
Tabel 2. Ketentuan Kriteria Penilaian Lembar Validasi Media

\begin{tabular}{cc}
\hline Persentase & Kriteria \\
\hline$\leq 20 \%$ & Tidak Layak \\
$21 \%-40 \%$ & Kurang Layak \\
$41 \%-60 \%$ & Cukup Layak \\
$61 \%-80 \%$ & Layak \\
$81 \%-100 \%$ & Sangat Layak \\
\hline
\end{tabular}

\section{PEMBAHASAN}

Pada bagian ini akan dibahas dari hasil pengembangan E-book sistem komputer berbasis android. Pembahasan meliputi perencanaan dan pengembangan Ebook sistem komputer, data hasil validasi serta data hasil uji coba kelayakan media.

\section{A. Tahap Analyze (Analisis)}

Pada tahap analisis ini penulis mengumpulkan informasi dengan melakukan wawancara terhadap guru berupa silabus, materi pembelajaran, buku ajar yang digunakan. Dari hasil wawancara yang dilakukan penulis kepada guru, penulis menganalisis KI dan KD yang dirasa sulit dipahami oleh peserta didik yang nantinya akan ditentukan materi yang akan diambil. Kemudian penulis menganalisis media lain untuk mempertimbangkan gambar-gambar atau button yang cocok untuk media E-book berbasis Android.

\section{B. Tahap Design (Desain)}

Pada tahapan desain ini penulis membuat rancangan storyboard terlebih dahulu agar media yang akan buat sesuai dengan konsep awalnya seperti pada gambar 3 .

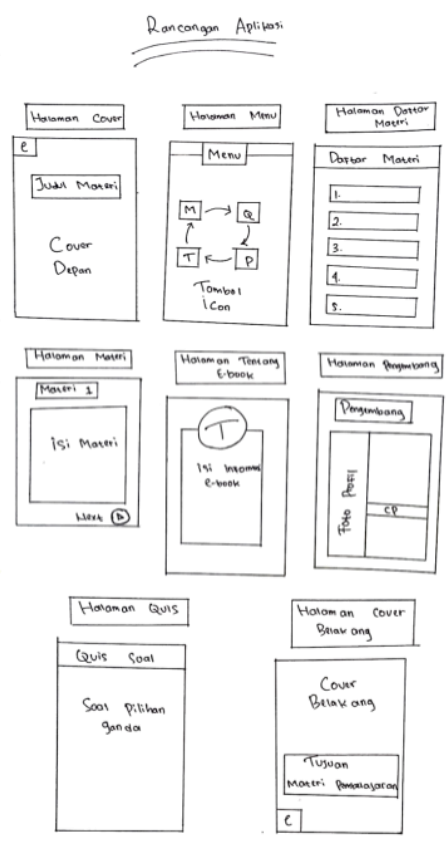

Gambar 3. Rancangan Pembuatan Aplikasi
Ada beberapa penilaian yang harus disesuaikan agar media E-book berbasis Android ini efektif untuk digunakan oleh peserta didik, seperti karakter, font, teks, button, background, serta pemilihan materi yang akan di masukkan kedalam media Ebook berbasis Android. Dari mempertimbangkan karakteristik media Ebook berbasis Android, seperti:

1) Self instructional.

2) Selfcontained.

3) Stand alone.

4) Adaptif.

5) User friendly.

6) Penggunaan font, spasi dan tata letak harus konsisten.

7) Penyampaiannya harus menggunakan media elektronik.

8) Pemanfaatan media elektronik agar menjadikan sebagai multimedia interaktif.

9) Pemanfaatan fitur yang ada pada aplikasi software.

\section{Tahap Develop (Pengembangan)}

Pada tahapan pengembangan ini menghasilkan sebuah produk yang sebelumnya dikembangkan dari tahap desain, tahap pengembangan ini menggunakan Flip PDF Corporate Edition yang biasa di gunakan khusus untuk pembuatan Aplikasi E-book. Berikut adalah isi dari media E-book.

\section{Halaman Depan/Cover}

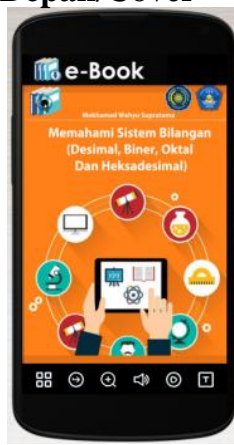

Gambar 4. Halaman Cover Depan

Pada gambar di atas menunjukkan halaman depan atau cover dengan isi, Judul materi yang akan di bahas yang ada pada halaman E-book tersebut agar peserta didik memahami pelajaran apa yang akan dipelajari didalam E-book ini nanti.

2. Menu Utama

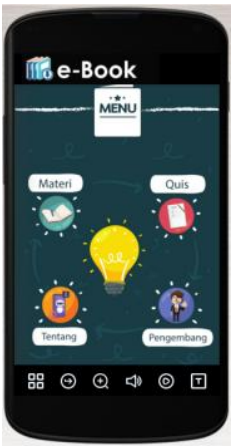

Gambar 5. Halaman Menu Utama 
Setelah dari halaman cover peserta didik akan masuk kehalaman berikutnya yakni halaman menu utama didalam menu utama ini terdapat beberapa button yang berisikan tentang materi, quis, tentang, pengembang.

\section{Halaman Materi}

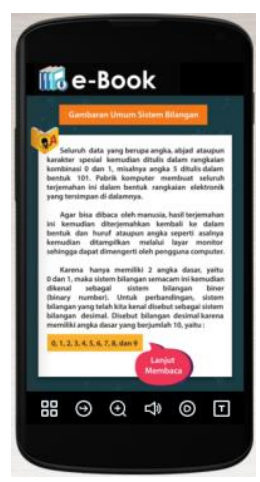

Gambar 6. Halaman Materi

Pada halaman materi ini peserta didik dapat menambah pemahaman tentang teori tentang mata pelajaran sistem komputer yang sudah dirancang sesuai kompetensi dasar, serta tujuan pembelajaran yang sudah ditetapkan.

\section{Halaman Quis}

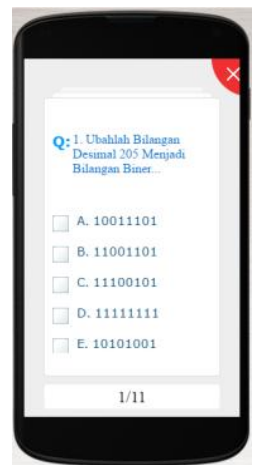

\section{Gambar 7. Halaman Quis}

Pada halaman ini peserta didik akan mengisi soal pilihan ganda dengan tujuan untuk mengevaluasi peserta didik apakah sudah memahami materi yang ada pada aplikasi E-book tersebut.

\section{Halaman Tentang E-book}

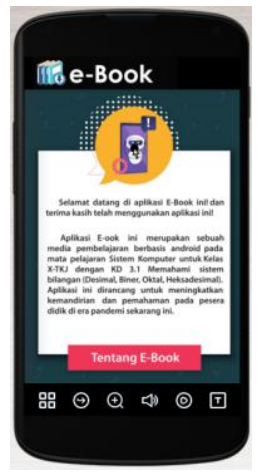

Gambar 7. Halaman Tentang E-book
Halaman ini bertujuan untuk menampilkan informasi kompetensi dasar serta tujuan pembelajaran yang digunakan dalam E-book tersebut, agar materi yang disampaikan tidak melebar ke materi yang lain.

\section{Halaman Profil Pengembang}

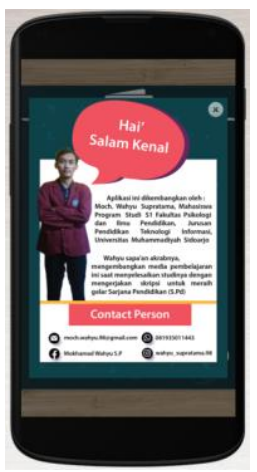

\section{Gambar 8. Halaman Profil Pengembang}

Pada halaman pengembang ini akan berisikan data diri pengembang meliputi nama pengembang, program studi serta jurusan yang diambil. Pada hamalan ini juga di jelaskan kanapa pengembang mengembangkan media E-book tersebut dilengkapi dengan beberapa kontak media sosial pengembang.

Hasil analisis data dari validasi ahli materi dan ahli media dapat ditunjukkan dibawah ini :

a. Validasi Ahli Media

Validasi ahli media dilakukan dengan melihat kualitas media E-book berbasis android sebagai media pembelajaran.

Tabel 3. Hasil Validator Ahli Media

\begin{tabular}{|cccc|}
\hline \multicolumn{4}{|c|}{ Validator : Akbar Wiguna, M.Pd } \\
\hline No & Instrumen & Presentase & Keterangan \\
1 & Media & $96 \%$ & Sangat Layak \\
\hline
\end{tabular}

b. Validasi Ahli Materi

Validasi ahli materi dilakukan terkait penjelasaian materi yang terdapat di media pembelajaran E-book.

Tabel 4. Hasil Validator Ahli Materi

\begin{tabular}{|cccc|}
\hline \multicolumn{4}{|c|}{ Validator : Moch. Sofi Asrifin, S.Kom } \\
\hline No & Instrumen & Presentase & Keterangan \\
1 & Materi & $84 \%$ & $\begin{array}{c}\text { Sangat } \\
\text { Layak }\end{array}$ \\
\hline
\end{tabular}

Hasil validasi dari ahli media dan ahli materi mendapatkan beberapa masukan diantaranya tertera pada Tabel 5 : 
Tabel 5. Saran Validator

\begin{tabular}{|l|l|l|}
\hline No & Validator & \multicolumn{1}{|c|}{ Masukan } \\
\hline 1 & Ahli Media & $\begin{array}{l}\text { Kurang petunjuk } \\
\text { penggunaan dalam media. }\end{array}$ \\
\hline 2 & Ahli Materi & $\begin{array}{l}\text { Alangkah baiknya untuk } \\
\text { Quis setelah di kerjakan } \\
\text { muncul Total skor } \\
\text { penilaian. }\end{array}$ \\
\hline
\end{tabular}

Revisi produk ini didasarkan hasil masukan dari validasi yang dilakukan oleh validator meliputi halaman penggunaan media dan materi soal yang ada dalam media E-book sistem komputer. Berikut adalah masukan dari validator yang sudah diperbaiki oleh penulis.

Tabel 6. Revisi Produk 1

\begin{tabular}{|l|l|l|}
\hline Produk awal & Produk akhir revisi \\
\hline If e-Book & \\
\hline & & \\
\hline
\end{tabular}

Setelah produk di revisi terdapat penambahan yaitu menu petunjuk serta halaman petunjuk penggunaan yang berfungsi agar peserta didik dapat memahami secara mandiri fungsi dari tombol yang ada dalam media E-book.

Tabel 7. Revisi Produk 2

\begin{tabular}{|l|l|}
\hline Produk Awal & Produk akhir revisi \\
\hline & \\
\hline & \\
\hline
\end{tabular}

Setelah produk di revisi terdapat penambahan yaitu terdapat Total Nilai hasil yang sudah dikerjakan oleh siswa.

Setelah media pembelajaran E-book berbasis android direvisi dengan baik maka selanjutnya melakukan tahap uji coba kepada peserta didik. Uji coba dilakukan di SMK Yapalis Krian pada hari Rabu tanggal 29 Juli 2021. Tahap ini dilakukan untuk mengetahui bagaimana respon peserta didik terhadap media pembelajaran E-book berbasis android yang telah dikembangkan dengan cara memberikan angket kepada peserta didik.

Angket yang diberikan terdiri dari 5 skala penilaian yaitu 5 (sangat setuju), 4 (setuju), 3 (cukup setuju), 2 (kurang), dan 1 (sangat kurang) dan dinilai dari aspek materi maupun pemograman media pembelajaran berbasis Android. Respon peserta didik terhadap media diperoleh dengan melibatkan 10 orang peserta didik kelas X-TKJ. Berdasarkan dengan penelitian (Arfah \& Fatisa, 2020) dengan dipilihnya 10 peserta didik tersebut dikarenakan saran dari guru dengan melihat kondisi sekarang yang terjadi di sekolah yaitu menerapkan metode daring sehingga waktu yang di gunakan cukup terbatas sehingga tidak bisa melibatkan seluruh siswa di dalam kelas.

Proses pengumpulan data tersebut dilakukan dengan cara memberikan media pembelajaran Ebook berbasis android melalui google drive yang kemudian dikirimkan kepada masing-masing peserta didik di download untuk digunakan dan peserta didik memberikan penilaiannya masing-masing sesuai dengan pernyataan dalam angket. Berdasarkan hasil analisis data, dengan 10 indikator yang diisi oleh 10 peserta didik dimana jumlah ratarata dari 10 siswa 91,4 dengan kriteria "Sangat Layak", sehingga secara keseluruhan media pembelajaran E-book berbasis Android sangat layak untuk digunakan dalam proses pembelajaran yang sesungguhnya di dalam kelas.

\section{Tahap Implement (Implementasi)}

Tahap dimana media E-book ini diterapkan kedalam sebuah proses pembelajaran yang sesungguhnya di kelas. Prosedur dalam tahap implementasi, yaitu mempersiapkan guru dan mempersiapkan murid. Pada prosedur mempersiapkan guru seperti memberi arahan serta panduan terkait penerapan media yang telah dikembangkan. Dan pada prosedur mempersiapkan siswa seperti memberi pengarahan kepada siswa sebelum pelaksanaan implementasi, meliputi alat yang dibutuhkan selama pembelajaran dengan media yang dikembangkan.

Dalam penelitian ini tidak akan sampai di tahap impelementasi ini dikarenakan masa pandemi covid 19 dan juga karena keterbatasan waktu yang di peroleh guru sehingga waktu pembelajaran tidak maksimal hal tersebut sesuai dengan ketentuan sekolah mengenai waktu setiap guru mengajar yang di berikan di batasi dalam mengajar. Jadi dengan pertimbangan tersebut penelitian yang di lakukan hanya sampai di tahap uji kelayakan produk yang dilakukan.

\section{E. Tahap Evaluation (Evaluasi)}

Produk yang sudah dikembangkan diperbaiki mengenai kualitas penerapan media yang di nilai 
efektif atau tidak dalam proses pembelajaran di kelas. Namun dalam penelitian ini tidak akan sampai di tahap evaluasi ini dikarenakan masa pandemi covid 19 dan juga karena keterbatasan waktu yang di peroleh guru sehingga waktu pembelajaran tidak maksimal hal tersebut sesuai dengan ketentuan sekolah mengenai waktu setiap guru mengajar yang di berikan di batasi dalam pembelajaran. Jadi dengan pertimbangan tersebut penelitian yang di lakukan hanya sampai di tahap uji kelayakan produk yang dilakukan.

\section{KESIMPULAN}

Berdasarkan hasil penelitian dan pengembangan produk yang dilakukan, maka dapat ditarik kesimpulan sebagai berikut :

1. E-book yang dikembangkan berupa produk aplikasi android sebagai media pembelajaran pada mata pelajaran sitem komputer. Proses pengembangan E-book sistem komputer berbasis android dengan mengunakan metode pengembangan ADDIE yang terdiri dari 5 tahap yaitu (1) Analisis, dengan menganalisis kebutuhan yang diperlukan di SMK Yapalis Krian. (2) Desain, dengan mendesain perancangan E-book seperti pembuatan konsep awal media. (3) Pengembangan, dengan menggunakan Flip PDF Corporate Edition yang biasa di gunakan khusus untuk pembuatan Aplikasi E-book. (4) Implementasi, melihat apakah media Ebook sistem komputer berbasis android ini lebih efektif dan membuat siswa lebih berpartisipasi dalam kegiatan belajar mengajar dari yang sebelumnya atau tidak. (5) Evaluasi, dengan mengevaluasi penerapan dari media yang sudah dilakukan di dalam kelas

2. Pengembangan media E-Book ini telah teruji kelayakannya karena sudah mendapatkan validasi dari ahli media dan ahli materi adapun presentase kelayakan media yang dinilai oleh ahli media mendapatkan presentase sebesar 96\% dengan kategori "Sangat Layak", untuk digunakan dan penilaian dari ahli materi mendapatkan presentase sebesar $84 \%$ dengan kategori "Sangat Layak" serta respon peserta didik dalam angket siswa mendapat nilai ratarata sebesar 91,4 dengan kategori "Sangat Layak" untuk digunakan dalam proses pembelajaran yang sesungguhnya di dalam kelas.

Saran yang dapat peneliti buat berdasarkan hasil penelitian pengembangan media pembelajaran berbasis android ini seperti berikut :

1. Guru :

a. Media E-book ini agar dapat dipakai oleh banyak siswa dengan mengunduhnya di aplikasi Play Store yang ada di android serta penambahan materi atau mata pelajaran lain agar E- book berbasis android ini bisa digunakan di berbagai macam pelajaran.

b. Memanfaatkan aplikasi ini untuk tujuan pembelajaran yang interaktif yang dapat menarik perhatian sehingga tidak merasa jenuh ketika proses belajar mengajar berlangsung, sehingga dapat menimbulkan suasana aktif di dalam kelas.

2. Peneliti selanjutnya :

a. Pengembangan media pembelajaran Ebook berbasis android masih dalam tahap uji kelayakan, dan diharapkan pada tahap selanjutnya dapat dilanjutkan ke tahap implementasi dan evaluasi untuk mengetahui keefektifan media pembelajaran ini.

b. Menambahkan fitur untuk update materi dan soal secara online sehingga aplikasi dapat digunakan secara berkelanjutan nantinya kedepannya.

c. Melakukan perbaikan dan pengembangan lebih lanjut pada E-book berbasis android menggunakan aplikasi File Pdf Corporatin agar meminimalkan gangguan penggunaan seperti lamanya waktu saat membuka tiap halaman dan mengurangi size ukuran aplikasi agar tidak terlalu besar sehingga bisa digunakan secara baik di smartphone masing-masing oleh siswa.

\section{PUSTAKA}

Alwan, M. (2018). Pengembangan Multimedia EBook 3D Berbasis. Jurnal At-Tadbir STAI Darul Kamal NW Kembang Kerang, I(2), 2640.

Anggraini, Y. D. (2020). Pengembangan Media Pembelajaran e-Book Novelmatika untuk Meningkatkan Pemahaman Konsep Statistika. Amanah: Jurnal Amanah Pendidikan Dan Pengajaran, 1(1), 35-48.

Arfah, N., \& Fatisa, Y. (2020). DESAIN DAN UJI COBA VIDEO STOP MOTION SEBAGAI MEDIA PEMBELAJARAN PERKEMBANGAN TEORI MODEL ATOM. Jurnal Pendidikan Kimia Universitas Riau, 5(2), 46. https://doi.org/10.33578/jpkunri.v5i2.7775

Arif S. Sadiman, D. (2014). Media pendidikan: pengertian, pengembangan dan pemanfaatannya. Depok: PT. Raja Grafindo Persada.

Arikunto. Suharsimi. (2014). Prosedur Penelitian Suatu Pendekatan Praktik. Rineka Cipta.

Arsyad, A. (2007). Pengertian Media. Media Pembelajaran, 3.

Ashshidiqqi, H. (2017). Pengembangan E-book Multimedia Interaktif Berbasis Flash pada 
Konsep Kingdom Animalia.

Endang, M. (2011). Metode Penelitian Terapan Bidang Pendidikan. Alfabeta.

Eskawati, S. Y., \& Sanjaya, I. G. M. (2012). Pengembangan E-Book Interaktif pada Materi Sifat Koligatif sebagai Sumber Belajar Siswa Kelas XII IPA. UNESA Journal of Chemical Education, 1(2), 46-53.

Faidah, S. (2015). Pengembangan Bahan Ajar Berbasis E-Book Menggunakan Kvisoft Flipbook Maker Untuk Kelas Viii Mts $N 2$ Kota Cirebon.

Gatot Pramono. (2008). Pemanfaatan Multimedia Pembelajaran (P. T. Informasi \& dan K. Pendidikan (eds.)). Departemen Pendidikan Nasional.

H Nazruddin Safaat. (2011). Pemrograman Aplikasi Mobile Smartphone dan Tablet PC Berbasis Android. Penerbit Informatika.

Hamdi, G., \& Krisnawati. (2011). Membangun Aplikasi Berbasis Android "Pembelajaran Psikotes" Menggunakan App Inventor. JURNAL DASI Vol. 12 No. 4 DESEMBER 2011, 12(4), 28.

Marbun, 2019. (2019). PENGEMBANGAN MEDIA PEMBELAJARAN ELECRONIC BOOK (EBOOK) BERBASIS EDMODO KELAS $\mathrm{X}$ SMK KARTIKATAMA METRO. Hubungan Pengetahuan Ibu Hamil Dan Tingkat Ekonomi Tentang Kejadian Stunting, 7(2), 14-15.

Mentari, D., Sumpono, S., \& Ruyani, A. (2018). Pengembangan media pembelajaran e-book berdasarkan hasil riset elektroforesis 2-d untuk mengukur kemampuan berpikir kreatif mahasiswa. PENDIPA Journal of Science Education, 2(2), 131-134. https://doi.org/10.33369/pendipa.2.2.131-134

Muhson, A. (2010). Pengembangan Media Pembelajaran Berbasis Teknologi Informasi. Jurnal Pendidikan Akuntansi Indonesia, 8(2). https://doi.org/10.21831/jpai.v8i2.949

Muyaroah, S., \& Fajartia, M. (2017). Pengembangan Media Pembelajaran Berbasis Android dengan menggunakan Aplikasi Adobe Flash CS 6 pada Mata Pelajaran Biologi. Innovative Journal of Curriculum and Educational Technology, 6(2), 22-26. https://doi.org/10.15294/ijcet.v6i2.19336

Oemar, H. (2002). Media Pendidikan.

Ruddamayanti, R. (2019). Pemanfaatan Buku Digital Dalam Meningkatkan Minat Baca. Prosiding Seminar Nasional Pendidikan Program Pascasarjana Universitas PGRI Palembaang., 2, 364-370.

Rusman. (2015). Pembelajaran Tematik Terpadu Teori Praktik dan Penilaian. Rajawali Pers.

Sugiyono. (2009). Metode Penelitian Kuantitatif, Kualitatif dan $R \& D$. Bandung : Alfabeta.

Sukmadinata, N. S. (2013). Metode Penelitian Pendidikan. PT Remaja Rosdakarya.
Suryani. Nunuk, dkk. (2018). Media Pembelajaran Inovatif dan Pengembangannya (Remaja Rosdakarya (ed.)).

Suryani, E., \& Khoiriyah, I. S. A. (2018). Pemanfaatan E-book sebagai Sumber Belajar Mandiri bagi Siswa SMA/SMK/MA. International Journal of Community Service Learning, 2(3), 177-184. https://doi.org/10.23887/ijcsl.v2i3.15422

Utari, S. Y. (2014). Pengembangan Media E-book Pada Mata Pelajaran Bahasa Inggris kelas X di SMA Negeri 2 Padang Panjang. 103.

Wahid Maulana, M. R. (2017). Pengembangan Aplikasi Android Untuk Studi Bahasa Carakan Madura. Journal of Information Engineering and Educational Technology, 1(1), 32. https://doi.org/10.26740/jieet.v1n1.p32-39 